\title{
1 Activities for Leptin in Bovine Trophoblast Cells
}

3 C. K. Hughes ${ }^{1}$, M. M. Xie ${ }^{2}$, S. R. McCoski and A. D. Ealy*

4 Department of Animal and Poultry Sciences, Virginia Polytechnic Institute and State University, 5 Blacksburg, VA 24061 USA.

6

$7 \quad{ }^{1}$ Present Address: Department of Animal Sciences, Pennsylvania State University, University

8 Park, PA 16802 USA

$9{ }^{2}$ Present Address: Department of Microbiology and Immunology, Indiana University School of

10 Medicine, Indianapolis, IN 46202 USA

11

12 *Corresponding author: Tel: (+1) 01-540-750-1222; email: ealy@ vt.edu

13

14

15

16

17

18

19

20

21

22

23

(C) 2016. This manuscript version is made available under the Elsevier user license http://www.elsevier.com/open-access/userlicense/1.0/ 


\section{ABSTRACT}

25 Leptin is involved in various reproductive processes in humans and rodents, including placental

26 development and function. The specific ways that leptin influences placental development and

27 function in cattle are poorly understood. This work was completed to explore how leptin

28 regulates hormone, cytokine and metalloprotease transcript abundance and cell proliferation in

29 cultured bovine trophoblast cells. In the first set of studies, cells were cultured in the presence of

30 graded recombinant bovine leptin concentrations $(0,10,50,250 \mathrm{ng} / \mathrm{mL})$ for 6- or 24-h.

31 Transcript profiles were examined from extracted RNA. Leptin supplementation did not affect

32 abundance of the maternal recognition of pregnancy factor, interferon-tau (IFNT), but leptin

33 increased $(P<0.05)$ abundance of chorionic somatomammotropin hormone $2(\mathrm{CSH} 2$; i.e.

34 placental lactogen) at both 6- and 24-h at each concentration tested. At 24-h, the greatest CSH2

35 abundance $(P<0.05)$ was detected in cells supplemented with $50 \mathrm{ng} / \mathrm{mL}$ leptin. Transcript

36 abundance of the remodeling factor, metalloprotease $2(M M P 2)$, was greater $(P<0.05)$ in leptin-

37 treated cells at 24-h but not at 6-h. The 24-h $M M P 2$ response was greatest $(P<0.05)$ at 250

$38 \mathrm{ng} / \mathrm{mL}$. Transcript abundance for $M M P 9$ was not altered by leptin treatment. In a separate set of

39 studies, cell proliferation assays were completed. Leptin supplementation did not affect CT1

40 proliferation at any dose tested. In conclusion, leptin supplementation did not affect bovine

41 trophoblast cell proliferation or IFNT expression, but leptin increases $C S H 2$ and $M M P 2$

42 transcript abundance. Both of these factors are involved with peri- and post-implantation

43 placental development and function, and this implicates leptin as a potential mediator of early

44 placental development and function in cattle.

\section{Keywords}

46 Placenta, trophectoderm, leptin, gene expression, cattle 


\section{Introduction}

Leptin is best known as an adipose-derived hormone that controls food intake and

49 adiposity in mammals, but leptin also has noted effects on reproduction in various mammals,

50 including cattle. The placenta is an apparent target of leptin action. There is an inverse

51 relationship between circulating leptin concentrations and placental size in early pregnancy and

52 at term in cattle [1]. Placenta-derived leptin may also influence pregnancy in cattle. Leptin and

53 its receptor are produced by the bovine pre-implantation embryo, placenta and endometrium

54 [2,3]. Placental leptin overexpression is associated with placentomegaly in nuclear transfer-

55 derived bovine pregnancies [3]. These abnormal pregnancies contain excessive trophoblast cell

56 proliferation and differentiation and produce greater circulating concentrations of placental

57 lactogen (now termed chorionic somatomammotropin hormone 2 [CSH2]), a hormone produced

58 by invasive binucleated trophectoderm cells [3]. Errors in methylation status within the leptin

59 promoter are implicated as one reason why leptin expression is altered in these nuclear-derived

60 pregnancies [4].

61 This work tested the hypothesis that leptin acts in various capacities to impact early

62 placental development and function in cattle. Studies were completed using a bovine trophoblast

63 cell line (CT1) [5]. This cell line possesses a pre-implantation stage morphology and gene

64 expression profile of bovine trophoblast cells and has been useful for describing how other

65 endometrial- and embryo-derived factors impact pre- and peri-implantation events in bovine

66 trophectoderm [5,6]. In this work, CT1 cells were used to explore how leptin supplementation

67 influences transcript profiles for several factors involved with maternal recognition of pregnancy

68 factor, placental differentiation and hormone production, and placental attachment and

69 implantation. 


\section{2. Materials and Methods}

\section{$72 \quad 2.1$ Bovine trophoblast cell culture}

73 The bovine trophoblast cell line, CT1, was cultured as described previously [5]. In brief,

74 cells were maintained on Matrigel ${ }^{\mathrm{TM}}$ Basement Membrane Matrix (BD Biosciences, Bedford,

75 MA) with Dulbecco's Modified Eagle's medium (DMEM; Thermo Fisher Scientific, Waltham,

76 ME, USA) containing $40 \mathrm{mM}$ glucose, $10 \%$ [v/v] fetal bovine serum (FBS; Life Technologies),

$77100 \mu \mathrm{M}$ non-essential amino acids (Thermo Fisher Scientific), $55 \mu \mathrm{M} \beta$-mercaptoethanol

78 (Thermo Fisher Scientific), and antibiotic/antimycotic (100 U/mL penicillin $\mathrm{G}, 100 \mu \mathrm{g} / \mathrm{mL}$

79 streptomycin sulfate, $250 \mathrm{ng} / \mathrm{mL}$ amphotericin B; Thermo Fisher Scientific). Cultures were

80 maintained at $38.5^{\circ} \mathrm{C}$ with $5 \% \mathrm{CO}_{2}$ in air. For both the transcript profiling work and the

81 proliferation assay, cells were serum-starved for 24-h prior to adding treatments.

82

$83 \quad 2.2$ Transcript profiling

84 Procedures were completed as described previously [7]. CT1 cells were seeded onto 685 well plates $\left(9.5 \mathrm{~cm}^{2} /\right.$ well) with a CellBIND® surface (Corning, Tewksburg, MA, USA) $(\sim 1 \mathrm{x}$

$8610^{5}$ cells/well). After 3 to 5 -d of growth (appr. 50\% confluency), cells were serum-starved for $1 \mathrm{~d}$

87 and then medium was replaced with fresh serum-free CT1 medium containing 0, 10, 50 or 250

$88 \mathrm{ng} / \mathrm{mL}$ recombinant bovine leptin. After either 6- or 24-h, total cellular (tc) RNA was extracted

89 using Trizol® and the PureLink® Micro-to-Midi Total RNA Purification System (Thermo Fisher

90 Scientific). Purity and quantity of RNA was determined using a NanoDrop 2000

91 Spectrophotometer (ThermoFisher Scientific). Only samples with an $\mathrm{A}_{260} / \mathrm{A}_{280}$ ratio $>1.8$ were

92 used. 
For quantitative (q) reverse transcription (RT) PCR [7], total RNA (10 ng/reaction) was

94 treated in RNase-free DNase (New England Biolabs, Ipwich, MA, USA) and reverse transcribed

95 (High Capacity cDNA Reverse Transcription Kit, Applied Biosystems, Austin, TX, USA). PCR

96 was completed using SYBR Green Master Mix reagent (Applied Biosystems) and specific

97 primer pairs (Table 1) using a RealPlex Master Cycler (Eppendorf, Hamburg, Germany). All

98 primers were validated for efficiency before use (range $=86-97 \%)$. Reactions were completed

99 with 40 amplification cycles using 58 to $60^{\circ} \mathrm{C}$ annealing/synthesis (depending on the primer set)

100 for $1 \mathrm{~min}$ and $95^{\circ} \mathrm{C}$ denaturation for 15 -sec. Amplification of a single PCR product was verified

101 for each PCR run by dissociation curve analysis. Non-reverse transcribed RNA samples were

102 included as negative controls. Ribosomal protein S9 (RPS9) served as the internal reference

103 control. RPS9 mRNA abundance did not differ based on leptin treatment (data not shown). The

104 threshold cycle $\left(\mathrm{C}_{\mathrm{T}}\right)$ values were expressed relative to the abundance of the reference control

$105 \quad\left(2^{-\mathrm{CT}(\text { transcript of interest) }} / 2^{-\mathrm{CT}(\mathrm{RPS} 9)}\right)[8]$.

106

1072.3 CT1 cell proliferation assay

108 This assay was completed as described previously [6]. In brief, cells were seeded onto

109 24-well plates $\left(1.9 \mathrm{~cm}^{2} /\right.$ well; $\left(\sim 1 \times 10^{4}\right.$ cells/well $)$. After 2 -d of growth and $1 \mathrm{~d}$ of serum-

110 starvation, medium was replaced with fresh serum-free CT1 medium containing 0, 10, 50 or 250

111 ng/mL recombinant bovine leptin (DevaTal Inc., Hamilton, NJ, USA). After 23 h, 5-ethynyl-2'-

112 deoxyuridine $(\mathrm{EdU} ; 100 \mu \mathrm{M})$ was added and cells were incubated for 45-min. Cells were fixed

113 (4\% [w/v] paraformaldehyde), and the Click-It ${ }^{\mathrm{TM}}$ EdU Cell Proliferation Assay containing Alexa

114 Fluor 488 detection (Thermo Fisher Scientific) was used to detect EdU-positive nuclei. Cells

115 were counterstained with Hoechst $33342(10 \mu \mathrm{g} / \mathrm{ml})$ to visualize all nuclei. The EdU-positive 
116 and total nuclei were counted in 5 representative fields (range: 30 to 150 cells/field) in each well

117 using NIS-Elements Software (Nikon Instruments Inc., Melville, NY) after capture with an

118 Eclipse Ti-E inverted microscope equipped with an X-Cite 120 epiflourescence illumination

119 system and DS-L3 digital camera (Nikon Instruments Inc.). Each treatment was assessed in three

120 wells in each replicate study. Mitotic index was calculated by averaging the percentage of EdU-

121 positive nuclei for all of the readings for each treatment.

122

\section{$123 \quad 2.4$ Statistical analysis}

124 Data were analyzed by ANOVA using the general linear model (GLM) of the Statistical

125 Analysis System (SAS institute, Cary, NC, USA) for the effects of leptin concentration on

126 outcomes. The $\mathrm{C}_{\mathrm{T}}$ ratio data were log-transformed before analysis. Individual means were

127 compared by pair-wise comparisons (PDIFF analysis, SAS). Data presented as arithmetic means

128 and SEM.

129

130 3. Results

131 The first set of studies examined potential roles for leptin in regulating early placental

132 hormone and cytokine production (Fig. 1). The first transcript examined was IFNT, the maternal

133 recognition of pregnancy factor in ruminants [9]. Leptin did not influence IFNT mRNA

134 abundance at either time point (Fig. 1A\&B). Two time periods (6-h and 24-h) were chosen for

135 this and other studies to maximize opportunities to detect leptin-dependent changes in gene

136 expression.

137 The second transcript examined was $\mathrm{CSH} 2$, which encodes placental lactogen, a well-

138 characterized placental hormone produced primarily by differentiated, binucleate cells (BNCs) in 
139 ruminants [10]. Increases $(\mathrm{P}<0.05)$ in $C S H 2 \mathrm{mRNA}$ abundance were detected at 6 and $24 \mathrm{~h}$ with

140 each leptin concentration tested (Fig. 1C\&D). After 6-h of treatment, each leptin concentration

141 increased ( $\mathrm{P}<0.05)$ CSH2 mRNA abundance to the same extent (Fig. 1C), but a biphasic leptin

142 dose-response was evident after 24-h of leptin exposure, where greater increases $(P<0.05)$ in

$143 \mathrm{CSH} 2 \mathrm{mRNA}$ abundance was detected in cells supplemented with $50 \mathrm{ng} / \mathrm{mL}$ leptin than when

144 treated with either 10 or $250 \mathrm{ng} / \mathrm{mL}$ (Fig. 1D).

145 Another set of transcripts examined were matrix metalloprotease-2 and -9 (MMP2/9).

146 Both enzymes play active roles in placental remodeling through gestation in cattle and other

147 ruminants [11]. The relative abundance of $M M P 2$ mRNA was unaffected by 6-h leptin exposure,

148 but a dose-dependent increase $(P<0.05)$ in $M M P 2$ abundance was detected after 24 -h leptin

149 supplementation (Fig. 2A\&B). No changes in $M M P 9$ mRNA abundance were evident after 6-h

150 or 24-h of leptin supplementation (Fig. 2C\&D).

151 A final study examined whether leptin serves as a mitogen in bovine trophoblast cells.

152 Supplementation with either $50-$ or $250-\mathrm{ng} / \mathrm{ml}$ leptin for $24 \mathrm{~h}$ did not affect the mitotic index of

153 CT1 cells (Fig. 3).

154

155 4. Discussion

156 This project was undertaken to fill a gap in knowledge pertaining to leptin actions in the

157 early developing bovine placenta. Much is known in cattle and other ruminants about leptin

158 actions relating to metabolism, adiposity and milk/meat production, but little work exists for

159 exploring actions of leptin within the bovine placenta. An expansive amount of information in

160 rodents and humans indicates that leptin controls trophoblast cell proliferation, placental cell 
161 survival and differentiation, placental hormone production, and implantation [12,13]. This work

162 explored if these events also are manipulated by leptin in bovine trophoblast cells.

163 The first action of leptin investigated was its ability to mediate trophoblast cell hormone

164 production. IFNT was examined because of its necessity for the establishment and maintenance

165 of pregnancy in ruminants [9]. Present findings indicate that leptin is not playing a direct role in

166 controlling IFNT expression. Previous work indicated that IFNT mRNA abundance mirrors

167 IFNT protein production [5]; therefore an effect for leptin on IFNT protein is unlikely. With that

168 said, indirect effects of leptin on maternal recognition of pregnancy are likely. Leptin and other

169 hormones (e.g. insulin-like growth factor 1, [IGF1]) altered by body condition and adiposity

170 impact uterine function, and this compromises conceptus development and IFNT production

$171[14]$.

172 The second hormone examined was $\mathrm{CSH} 2$. This prolactin-like hormone is produced by

173 the invasive and fusogenic binucleate cells (also known as trophoblast giant cells) from d 21 of

174 pregnancy onward [15]. CSH2 is involved with various maternal adaptations to pregnancy in

175 ruminants, including systemic effects such as increasing liver $I G F I$ and IGFBP3 mRNA

176 abundance [16] and local effects such as promoting uterine gland secretions [17]. An association

177 between leptin and CSH2 expression has been made previously. Both leptin and CSH2 mRNA

178 abundance are increased in nuclear transfer-derived pregnancies [3]. It is not clear if leptin is the

179 causative factor regulating $\mathrm{CSH} 2$ expression in these pregnancies, but the current work supports

180 the contention that leptin serves in this capacity.

181 The positive effect of leptin on $\mathrm{CSH} 2$ expression also may encourage the continued use

182 of CT1 cells to study $\mathrm{CSH} 2$ gene expression. Previous examinations of bovine or ovine $\mathrm{CSH} 2$

183 expression regulation required heterologous transfection studies using human and rodent 
184 choriocarcinoma lines [18,19]. Marginal CSH2 expression occurs in bovine trophoblast cell

185 lines, including CT1 cells under normal growth conditions. This likely is due to the low

186 incidence of binucleate cell formation in these cultures. Inducing binucleate cell development is

187 challenging in these cultures [20]. It was interesting to observe increases in CT1 cell CSH2

188 expression in the absence of binucleate cell formation, as observed by visual inspection of cell

189 morphology. Thus, CT1 cells may serve as a useful homologous cell system to study CSH

190 expression in ruminants.

191 The third set of factors examined were the gelatinases, MMP2 and MMP9. These

192 enzymes have been linked with key trophoblast invasion and placental remodeling events in

193 mammals, including ruminants [21,22]. The interest in examining leptin as a controller of MMP2

194 and MMP9 was inspired by previous work observing increases in placental invasion and

195 placentomegaly in placentae of nuclear transfer-derived pregnancies, which contain elevated

196 leptin expression [3]. In CT1 cells, leptin stimulated MMP2 mRNA abundance but not $M M P 9$

197 abundance. This is the first examination of leptin in bovine placental cells. Work in human

198 cytotrophoblast cells also found that leptin preferentially increased MMP2 mRNA abundance

199 [12]. Unfortunately, the present study did not examine MMP activity. Leptin promotes both

200 MMP2 and MMP9 enzyme activities in human placental cells [12,23]. Observing the same

201 effects in bovine placental cells will be needed to firmly establish the link between leptin and

202 placental remodeling in cattle.

203 It was interesting to note that leptin did not influence MMP2 mRNA abundance after 6-h

204 of treatment. Rather, 24-h was required to detect a leptin effect. The extended timing of this

205 response suggests that leptin is not acting through a direct signaling cascade to stimulate $M M P 2$

206 transcription and/or limit MMP2 mRNA degradation. Instead, an indirect action of leptin, 
207 wherein leptin stimulates regulatory factors that must undergo transcription/translation before

208 they can promote $M M P 2$ transcription likely occurred.

209 The final study examined whether leptin serves as a proliferative factor in bovine

210 placental cells. Leptin's role as a proliferative agent in trophoblast cells is ambiguous in other

211 species $[24,25]$. This work determined that leptin does not facilitate proliferation in bovine

212 trophoblast cells. However, leptin may act by other means to promote trophoblast survival in

213 cattle. Leptin is an anti-apoptotic factor in various cell types, including placental and embryonic

214 cells [24]. Leptin also contains embryotrophic activities. It enhances bovine oocyte fertilization

215 and subsequent embryo competency [26,27]. Therefore, leptin may well serve to control

216 embryonic and early placental development through mechanisms other than directly influencing

217 the mitogenic activity of cells.

218 In conclusion, the positive effect of leptin supplementation on $C S H 2$ and $M M P 2$

219 expression in bovine trophoblast cells and the lack of effects on IFNT expression and cell

220 proliferation suggest that leptin may be acting as mediator of implantation and post-implantation

221 hormone production in cattle. The work also suggests that leptin likely does not function as a

222 mitogen in trophoblast cells. However, the positive effects of leptin on oocyte and embryo

223 development in previous studies and present work describing positive effects of leptin on $\mathrm{CSH} 2$

224 and $M M P 2$ expression implicate leptin as a mediator of embryonic development and

225 implantation in cattle.

226

\section{Acknowledgments}

228 This project was supported by the National Research Initiative Competitive Grant no.

229 2011-67105-30688 from the USDA National Institute of Food and Agriculture. Funding was also 
provided by the J. L. Pratt Undergraduate Nutrition Research Scholarship to support

undergraduate research for C. K. Hughes.

\section{References}

234 [1] Sullivan TM, Micke GC, Magalhaes RS, Phillips NJ, Perry VE. Dietary protein during gestation affects placental development in heifers. Theriogenology 2009;72:427-438. [2] Madeja ZE, Warzych E, Peippo J, Lechniak D, Switonski M. Gene expression and protein distribution of leptin and its receptor in bovine oocytes and preattachment embryos produced in vitro. Animal 2009;3:568-578.

[3] Ravelich SR, Shelling AN, Ramachandran A, Reddy S, Keelan JA, Wells DN, Peterson AJ, Lee RS, Breier BH. Altered placental lactogen and leptin expression in placentomes from bovine nuclear transfer pregnancies. Biol Reprod 2004;71:1862-1869.

[4] Kremenskoy M, Kremenska Y, Suzuki M, Imai K, Takahashi S, Hashizume K, Yagi S, Shiota K. Epigenetic characterization of the cpg islands of bovine leptin and pou5f1 genes in cloned bovine fetuses. J Reprod Dev 2006;52:277-285.

[5] Michael DD, Alvarez IM, Ocon OM, Powell AM, Talbot NC, Johnson SE, Ealy AD.

Fibroblast growth factor- 2 is expressed by the bovine uterus and stimulates interferon-tau production in bovine trophectoderm. Endocrinology 2006;147:3571-3579.

[6] Xie M, McCoski SR, Johnson SE, Rhoads ML, Ealy AD. Combinatorial effects of epidermal growth factor, fibroblast growth factor 2 and insulin-like growth factor 1 on trophoblast cell proliferation and embryogenesis in cattle. Reprod Fertil Dev 2015.

[7] Yang QE, Johnson SE, Ealy AD. Protein kinase c delta mediates fibroblast growth factor-2induced interferon-tau expression in bovine trophoblast. Biology of Reproduction 2011;84:933943.

[8] Yang QE, Fields SD, Zhang K, Ozawa M, Johnson SE, Ealy AD. Fibroblast growth factor 2 promotes primitive endoderm development in bovine blastocyst outgrowths. Biol Reprod 2011;85:946-953.

[9] Ealy AD, Yang QE. Control of interferon-tau expression during early pregnancy in ruminants. American Journal of Reproductive Immunology 2009;61:95-106.

[10] Warren WC, Keisler DH, Anthony RV. Synthesis and secretion of ovine placental lactogen and its biochemical properties. Domest Anim Endocrinol 1990;7:331-342.

[11] Kizaki K, Ushizawa K, Takahashi T, Yamada O, Todoroki J, Sato T, Ito A, Hashizume K. Gelatinase (mmp-2 and -9) expression profiles during gestation in the bovine endometrium. Reprod Biol Endocrinol 2008;6:66.

[12] Castellucci M, De Matteis R, Meisser A, Cancello R, Monsurro V, Islami D, Sarzani R, Marzioni D, Cinti S, Bischof P. Leptin modulates extracellular matrix molecules and metalloproteinases: Possible implications for trophoblast invasion. Mol Hum Reprod 2000;6:951-958.

[13] Schulz LC, Widmaier EP, Qiu J, Roberts RM. Effect of leptin on mouse trophoblast giant cells. Biol Reprod 2009;80:415-424. 
[14] Wiltbank MC, Baez GM, Garcia-Guerra A, Toledo MZ, Monteiro PL, Melo LF, Ochoa JC, Santos JE, Sartori R. Pivotal periods for pregnancy loss during the first trimester of gestation in lactating dairy cows. Theriogenology 2016;86:239-253. [15] Patel OV, Yamada O, Kizaki K, Todoroki J, Takahashi T, Imai K, Schuler LA, Hashizume $\mathrm{K}$. Temporospatial expression of placental lactogen and prolactin-related protein-1 genes in the bovine placenta and uterus during pregnancy. Mol Reprod Dev 2004;69:146-152. [16] Currie MJ, Bassett NS, Breier BH, Klempt M, Min SH, Mackenzie DD, McCutcheon SN, Gluckman PD. Differential effects of maternal ovine placental lactogen and growth hormone (gh) administration on gh receptor, insulin-like growth factor (igf)-1 and igf binding protein-3 gene expression in the pregnant and fetal sheep. Growth Regul 1996;6:123-129.

[17] Spencer TE, Gray A, Johnson GA, Taylor KM, Gertler A, Gootwine E, Ott TL, Bazer FW. Effects of recombinant ovine interferon tau, placental lactogen, and growth hormone on the ovine uterus. BiolReprod 1999;61:1409-1418.

[18] Jeckel KM, Limesand SW, Anthony RV. Specificity protein-1 and -3 trans-activate the ovine placental lactogen gene promoter. Mol Cell Endocrinol 2009.

[19] Liang R, Limesand SW, Anthony RV. Structure and transcriptional regulation of the ovine placental lactogen gene. European journal of biochemistry / FEBS 1999;265:883-895.

[20] Koshi K, Suzuki Y, Nakaya Y, Imai K, Hosoe M, Takahashi T, Kizaki K, Miyazawa T, Hashizume K. Bovine trophoblastic cell differentiation and binucleation involves enhanced endogenous retrovirus element expression. Reprod Biol Endocrinol 2012;10:41.

[21] Cohen M, Bischof P. Factors regulating trophoblast invasion. Gynecol Obstet Invest 2007;64:126-130.

[22] Ulbrich SE, Meyer SU, Zitta K, Hiendleder S, Sinowatz F, Bauersachs S, Buttner M, Frohlich T, Arnold GJ, Reichenbach HD, Wolf E, Meyer HH. Bovine endometrial metallopeptidases mmp14 and mmp2 and the metallopeptidase inhibitor timp2 participate in maternal preparation of pregnancy. Mol Cell Endocrinol 2011;332:48-57.

[23] Gonzalez RR, Devoto L, Campana A, Bischof P. Effects of leptin, interleukin-1alpha, interleukin-6, and transforming growth factor-beta on markers of trophoblast invasive phenotype: Integrins and metalloproteinases. Endocrine 2001;15:157-164.

[24] Magarinos MP, Sanchez-Margalet V, Kotler M, Calvo JC, Varone CL. Leptin promotes cell proliferation and survival of trophoblastic cells. BiolReprod 2007;76:203-210.

[25] Schulz LC, Widmaier EP. The effect of leptin on mouse trophoblast cell invasion. Biol Reprod 2004;71:1963-1967.

[26] Arias-Alvarez M, Bermejo-Alvarez P, Gutierrez-Adan A, Rizos D, Lorenzo PL, Lonergan P. Effect of leptin supplementation during in vitro oocyte maturation and embryo culture on bovine embryo development and gene expression patterns. Theriogenology 2011;75:887-896. [27] Boelhauve M, Sinowatz F, Wolf E, Paula-Lopes FF. Maturation of bovine oocytes in the presence of leptin improves development and reduces apoptosis of in vitro-produced blastocysts. Biol Reprod 2005;73:737-744. 
312 Table 1. Primer sequences used to complete quantitative RT-PCR.

\begin{tabular}{|l|l|}
\hline Gene Name & Primer Sequence (5' to 3') \\
\hline CSH2 & $\begin{array}{l}\text { Forward: CGGATTCCCTTCAAAGCCT } \\
\text { Reverse: CCTCAACAGGGCTTCGTCAA }\end{array}$ \\
\hline$I F N T$ & $\begin{array}{l}\text { Forward: GCCCGAATGAACAGACTCTC } \\
\text { Reverse: CCATCTCCTGAGGAAGACCA }\end{array}$ \\
\hline$M M P 2$ & $\begin{array}{l}\text { Forward: GGCATCTCTCAGATCCGTGG } \\
\text { Reverse: TGTGGGTCTTCGTACACAGC }\end{array}$ \\
\hline$M M P 9$ & $\begin{array}{l}\text { Forward: AGGGTAAGGTGCTGCTGTTC } \\
\text { Reverse: AGGAGGTCGAAGGTCACGTA }\end{array}$ \\
\hline RPS9 & $\begin{array}{l}\text { Forward: GAGCTGGGTTTGTCGAAA } \\
\text { Reverse: GGTCGAGGCGGGACTTCT }\end{array}$ \\
\hline
\end{tabular}

$313 *$ All primers were chosen based on Primer Design Software from NCBI. 
Figure Legends:

318

319 Figure 1. Bovine leptin supplementation does not affect IFNT expression but increases

320 CSH2 mRNA abundance in bovine trophoblast cells. CT1 cells were exposed to 0, 10, 50 or

$321250 \mathrm{ng} / \mathrm{mL}$ recombinant bovine leptin for either $6 \mathrm{~h}$ (Panels A \& C; $\mathrm{n}=3$ replicate studies) or $24 \mathrm{~h}$

322 (Panels B \& D; $n=4$ replicate studies), and then RNA was extracted and analyzed to quantify

323 the relative abundance of IFNT (Panels A \& B) and CSH2 (Panels C \& D) mRNA. Different

324 superscripts within each panel represent differences $(\mathrm{P}<0.05)$.

325

326 Figure 2. Bovine leptin supplementation increases MMP2 mRNA abundance but does not

327 affect MMP9 abundance in bovine trophoblast cells. CT1 cells were exposed to 0, 10, 50 or

$328250 \mathrm{ng} / \mathrm{mL}$ recombinant bovine leptin for either $6 \mathrm{~h}$ (Panels A \& C; $\mathrm{n}=5$ replicate studies) or $24 \mathrm{~h}$

329 (Panels B \& D; $n=5$ replicate studies), and then RNA was extracted and analyzed to quantify

330 the relative abundance of MMP2 (Panels A \& B) and MMP9 (Panels C \& D) mRNA.

331 Different superscripts within each panel represent differences $(\mathrm{P}<0.05)$.

332

333 Figure 3. Bovine leptin supplementation does not affect bovine trophoblast cell

334 proliferation. CT1 cells were serum-starved overnight, and then were challenged with $0,10,50$

335 or $250 \mathrm{ng} / \mathrm{mL}$ recombinant bovine leptin. After $23 \mathrm{~h}$, EdU reagent was added for $45 \mathrm{~min}$, and

336 then cells were processed and examined by epifluorescence microscopy for the percentage of

337 EdU positive cells (Mitotic Index) ( $\mathrm{n}=3$ replicate studies). Different superscripts within each

338 panel represent differences $(\mathrm{P}<0.05)$.

339

340 
A

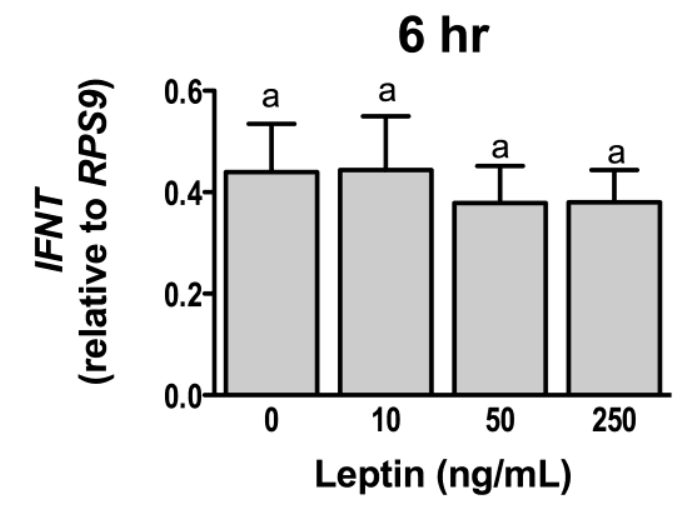

C

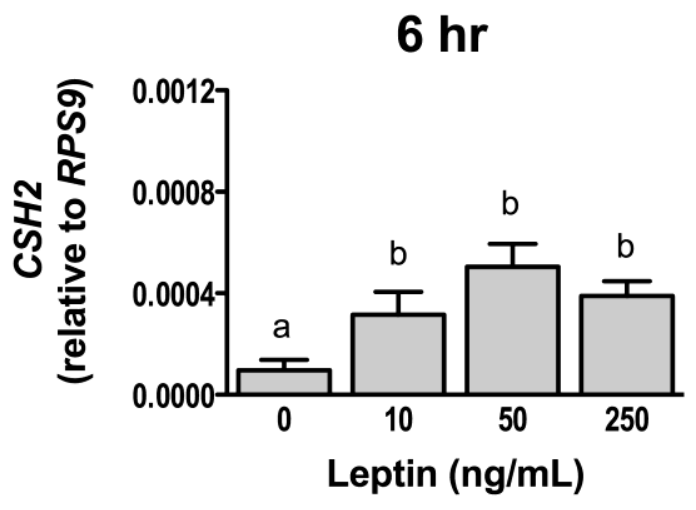

B

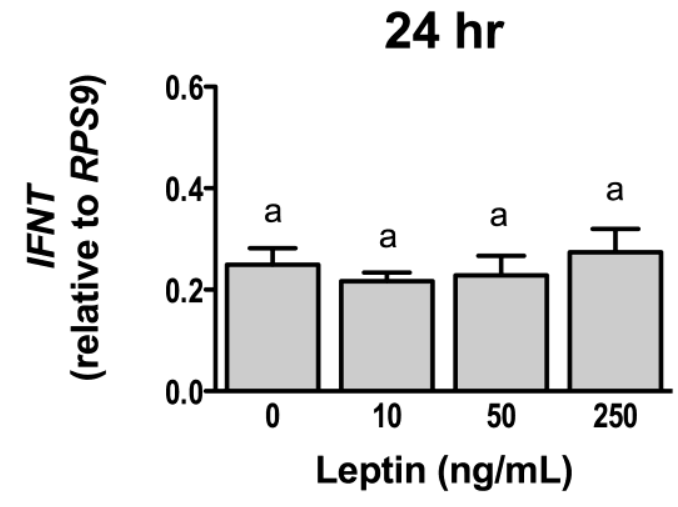

D

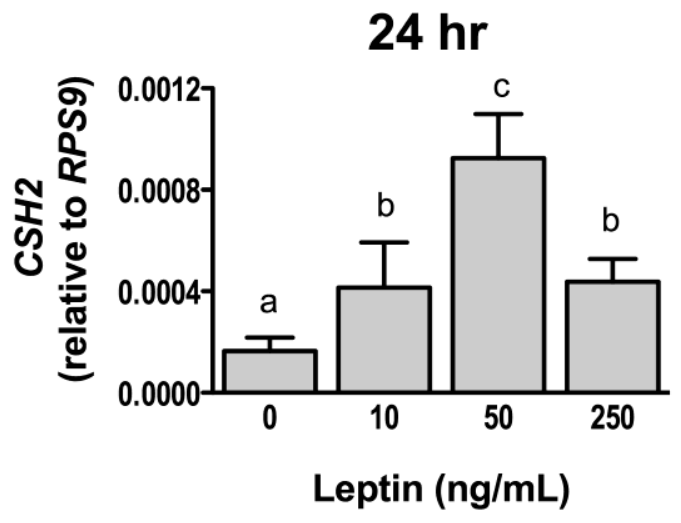


A

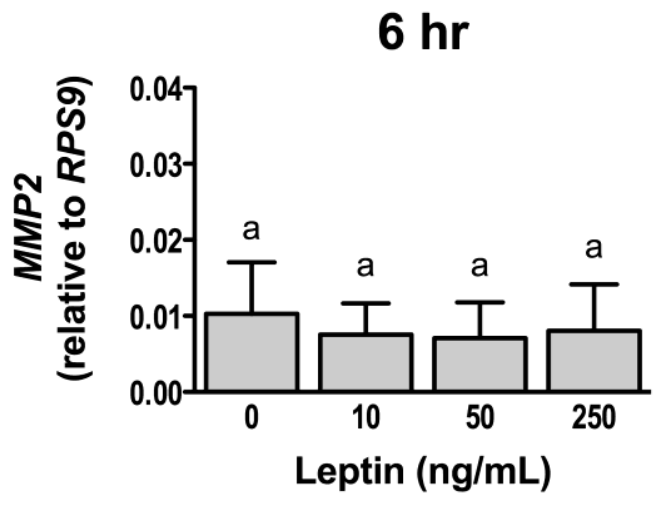

C

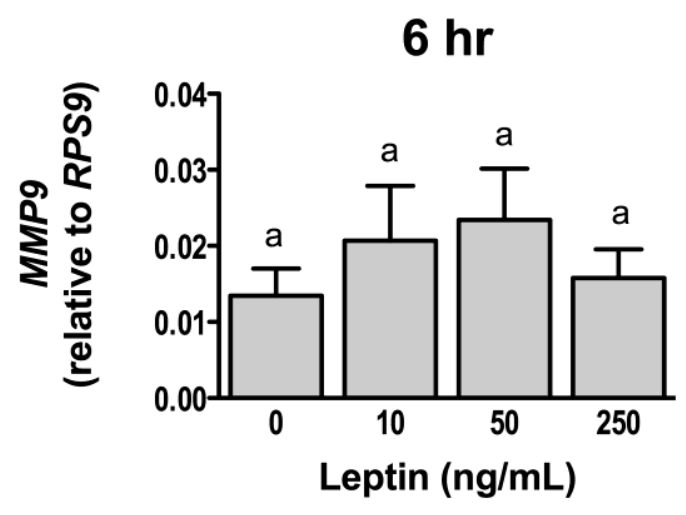

B

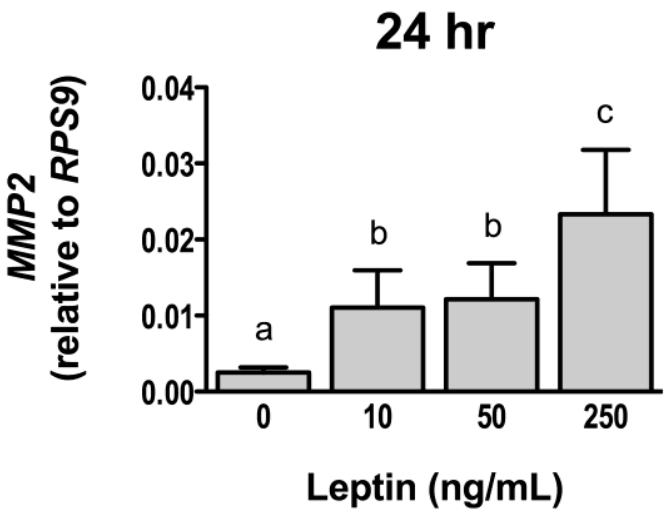

D

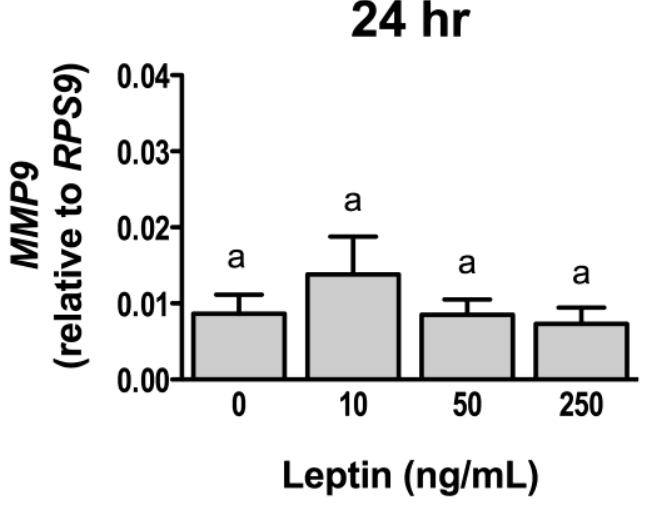




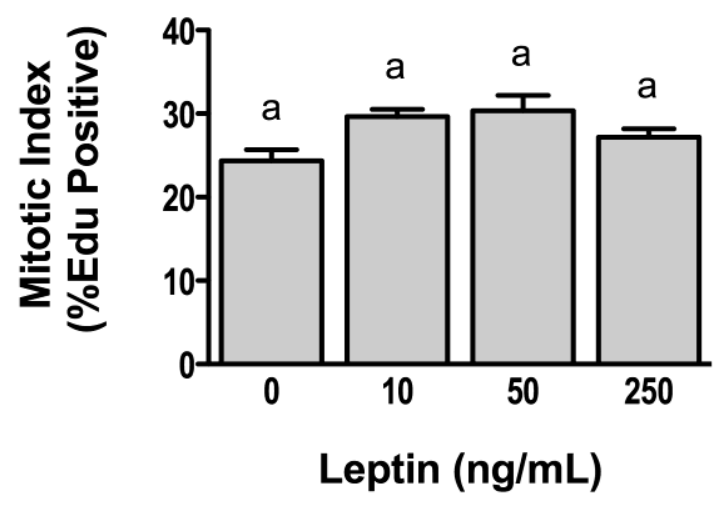

